\title{
ENERGY AUDIT AND EVALUATION OF SPECIFIC ENERGY CONSUMPTION OF LIGHTING SYSTEMS IN A NEW BUILDING: A KASETSART UNIVERSITY CASE STUDY
}

Original scientific paper

UDC: $351.824 .11: 628.972$

https://doi.org/10.18485/aeletters.2021.6.4.3

\author{
Worasitti Sriboon ${ }^{1 *}$, P. Pungboon Pansila ${ }^{1}$, Soontree Khunthong ${ }^{1}$, Saksit Sukprasong ${ }^{1}$ \\ ${ }^{1}$ Faculty of Science at Si Racha, Kasetsart University Si Racha Campus, Chon Buri 20230, Thailand
}

\begin{abstract}
:
Lighting systems are used in all building types and consume large amounts of energy as well as adding to carbon dioxide $\left(\mathrm{CO}_{2}\right)$ emissions. The aim of this research was to analyze energy consumption in the lighting systems of a new building. This study conducted a preliminary energy consumption audit of the Faculty of Science on the Kasetsart University Sriracha Campus, Thailand. The actual energy consumption in the study period and the specific energy index (specific energy consumption) were assessed. The results showed that the total electric power of all bulbs in the building was $72.13 \mathrm{~kW}$ and about $74 \%$ were $20 \mathrm{~W}$ lamps. Annual energy consumption and carbon dioxide emissions were 157,753.73 kWh and 89,477.92 kg carbon dioxide for 9 hours use. The total energy consumption accounted for $1.64 \%$ and $4.37 \%$ based on 9 and 24 hours operation, respectively. The specific energy index was higher than the average for this university. Therefore, the energy consumption data obtained are very important in developing energy-saving measures.
\end{abstract}

ARTICLE HISTORY

\section{INTRODUCTION}

Nowadays, energy demands in Thailand are increasing with economic activity and social changes in technology [1]. These issues are affecting an environmental topic that is of global concern, namely the emission of $\mathrm{CO}_{2}[2,3]$. Electrical energy is very important in the lives of humans $[4,5]$ such as daily activities that include supporting both public and private businesses in industrial production processes [6].

Globally, buildings involve high energy consumption and emit greenhouse gases $[7,8]$. Many research reports have revealed that energy consumption in a building is about $30-40 \%$ of the total energy consumption $[9,10]$. The lighting system is very important in a building [11] accounting for $20-45 \%$ of total energy consumption [12] with examples including Korea at around 30\% [13], the USA at around $25 \%$ and the EU at $14 \%$ [9].
In Thailand, energy consumption for lighting is around 25\% [14].

Electricity plays an important role in the operation of institutional buildings such as those on a university campus, including classroom management, laboratories, offices, meeting rooms, and lecturers' offices. The lighting system is very important for facilitating teaching and providing suitable room conditions and consequently it is a major part of high energy consumption $[15,16]$. In Thailand, data on the energy consumption in such buildings is around 10-30\% [17]. Any institution or university using more than $60 \mathrm{MJ}$ of electricity or having electrical usage of $1,000 \mathrm{~kW}$, or with a total transformer load of 1,175 kVA or more is considered a controlled building under a decree in 1995 under the Energy Conservation Promotion Act (ECP Act) of Thailand (1992) that was revised in 2007 [18]. In addition, the institution or university must comply with the ministerial regulations issued 
under the ECP Act. Thus, energy management must be carried out in those educational institutions, as an important tool for the efficient use of energy [19] and to help save on operating costs that each institution must pay for itself [20].

Surveys and audits of the energy consumption of lighting systems are constantly increasing due to user behavior and the availability of more modern technology. For example, Yun, et al. in [21] conducted a field survey for an open-air office in Seoul, Korea on the adaptive behavior of residents, which is a key factor affecting energy consumption a building's lighting. Yun and Kim in [13] assessed the predictive accuracy of lighting energy consumption using the EnergyPlus program and the integrated simulation method (ISM). They found that lighting energy consumption from the EnergyPlus program in conjunction with ISM reduced actual consumption by $24.6 \%$. Shailesh, et al. in [22] conducted a lighting audit on the level of light distribution in a school classroom and found that the lighting system was designed to be $25 \%$ bright than necessary. Addressing this could reduce energy consumption by $35 \%$ and also reduce energy costs. Salvadori, et al. in [23] analyzed the energy consumption of a lighting system in a public historical building in Pisa, Italy and identified energy monitoring activities and the possibility of achieving significant energy savings by improving the lighting system that had a short payback period and could reduce electricity consumption by 1.1$39.0 \mathrm{MWh} /$ year. Leccese, et al. [24] compared office building illumination between fluorescent lamps and LED lamps using a software program and constructed a mathematical model using the results of a lighting energy numerical indicator to calculate the annual energy consumption from lighting, to estimate the savings in operating costs, energy-saving and $\mathrm{CO}_{2}$ emissions, and to determine the payback period for lamp replacement. The results showed that the use of LED bulbs could save a significant amount of electricity. Kim, et al. in [25] surveyed real energy use in Korean medium-sized school academies including the relationship between the area, number of classes, students, and facilities In addition, they investigated energy-saving strategies for the lighting system, air conditioning system, and other utilities. Their results showed a continually increasing trend in energy consumption. Ali, et al. [26] conducted an energy consumption audit to analyze energy consumption patterns and potential energy conservation opportunities at Universiti Malaya. They reported found that lighting was the second most energy-efficient component, accounting for $18 \%$ of total energy consumption based on switching to LED light bulbs that used up to 144,386 $\mathrm{kWh} /$ year. From the literature review, there are many ways to potentially save energy consumption by a commercial lighting system. Although using energy software is more convenient for energy consumption analysis, the software is costly and not as accurate as actual measurement because some software may not consider electrical losses or differences in user behavior.

Kasetsart University, is Thailand' leading autonomous government university and has a policy that promotes being a Green University on all campus sites. Thus, the conservation of energy and optimizing the use of energy for maximum benefit in the future are important matters in accordance with this policy. An efficient and sustainable plan requires the assessment of the energy conservation potential, so that performance is appropriate and consistent within a university context. The objective of this research was to survey and measure energy consumption in building lighting systems using a Kasetsart University campus as the study area based on a newly constructed building not yet opened, to provide the foundation for planning energy-efficiency management before the official opening of the building $[23,27]$. In addition, rather than using nameplate data which is a popular and convenient way to collect data [28], a more accurate method using an energy indicator was applied to find ways to improve lighting energy use where appropriate.

\section{BUILDING ENERGY EVALUATION}

\subsection{Energy management}

Energy consumption assessment is a part of the energy management system according to Thailand's Energy Conservation Promotion Act (No.2), B.E. 2550 (2007). The process of energy management must be in accordance with the standards set in the ministerial regulations. Criteria and methods of energy management as defined in the regulations for a Controlled Factory and Controlled Building (2009) can be divided into 8 steps [29]. The energy potential assessment stage in the 4th step is designed to discover the potential of the organization to improve energy efficiency and to be used as a guideline for determining energy conservation measures and improving energy efficiency. Energy equipment data are collected, 
energy audits are undertaken, and energy consumption is analyzed. Once collated, the information is used as a guideline for setting goals and planning for energy conservation

\subsection{Energy consumption calculation}

The electric power was calculated using equation 1 :

$$
P=V I \cos \theta / 1,000
$$

where: $P$ is the electric power $[\mathrm{kW}], V$ is the electric potential $[\mathrm{V}], I$ is the current $[\mathrm{A}]$, and $\cos \theta$ is the power factor. The daily energy consumption can be obtained from equation 2 [30]:

$$
Q=n P_{i} t
$$

where: $Q$ is the daily energy consumption, $n$ is the number of lamps, $P_{i}$ is the electric power of each type of lamp [kW], and $t$ is the amount of time used [hour]. Thus, the annual electric consumption was calculated using equation 3 [31]:

$$
E=Q D
$$

where: $E$ is the annual electric consumption [kWh] and $D$ is the number of days per year.

\subsection{Specific energy consumption}

Specific energy consumption (SEC) is an index used to determine energy efficiency in relation to the usable area of a building. The index must survey and collect data on the energy consumption and utilization characteristics of each office building to determine the energy use and the appropriate criteria for energy use per specific area that can be applied to determine suitable energy conservation. SEC was calculated using equation 4 [32]:

$$
S E C=E / A
$$

Where: $A$ is the area $\left[\mathrm{m}^{2}\right]$.

\section{FIELD INVESTIGATION AND METHOD}

\subsection{Case study building}

This study selected the Faculty of Science Sriracha Building (Fig.1) within the Kasetsart University Sriracha campus in Chonburi province, Thailand. The building consisting of 13 floors was completed in 2019. The total population using the building is approximate 1,380 people, including students and staffs. The building's scheduled operating times are Monday-Friday, 8:30 a.m-4:30 p.m. (8 hours). However, some classes are scheduled for 4:30-7:30 p.m. The building has a total usable area of $15,077.95 \mathrm{~m}^{2}$ with 193 rooms in total, comprising classrooms, meeting rooms, office rooms, and lecturers' offices.

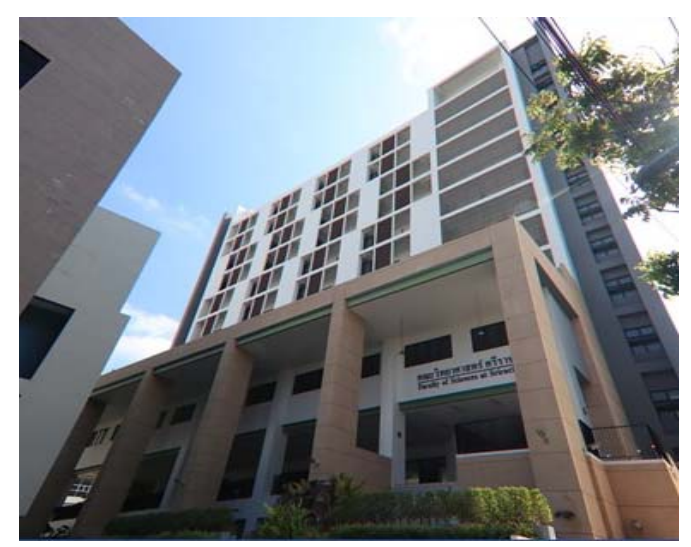

Fig. 1. Building in Faculty of Science, Sriracha

\subsection{Methodology of work}

The survey and data collection on the energy consumption of the building's lighting systems were carried out as follows:

- Plans for the electrical and lighting systems within the building were considered as a starting point for investigating the number of devices, power consumption from nameplate data, installation locations of distribution system cabinets to various devices, and the space in each room;

- A walk-through survey on the actual site was conducted to compare with the plan details;

- Preliminary energy consumption was measured using a digital power clamp meter model 1660 (PeakTech) (Fig.2). The power meter was recorded every 1 minute for 60 minutes using power energy mode. As the lighting system had a large number of lamps of different sizes, the electricity supply to the lighting system comes from the sub-distribution board (SBD), requiring a large number of devices to be measured. Therefore, the audits to assess energy consumption were performed using the Taro Yamane statistical method to estimate a random number of lamps [33] at the $95 \%$ confidence level with a sample error of 0.05 . The sample group of lamps used to measure energy consumption was: 20 W LED lamps (346 samples), 8 W LED lamps (33 samples), 9 W LED lamps (213 samples), and 7 W LED lamps (207 samples), totaling 799 samples; 
- The analysis simulated a teaching situation at the university, divided into 3 periods: 9:00 a.m.12:00 noon, 1:00-4:00 p.m., and 4:30-7:30 p.m.

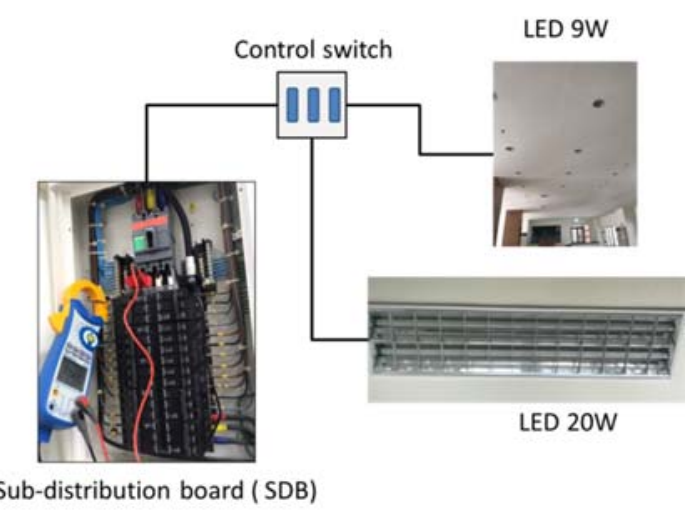

Fig. 2. Method of measuring electrical energy using a meter at the sub - distribution board

\section{RESULTS AND DISCUSSION}

\subsection{Electricity use in building lighting system}

The audits documented 3,483 light bulbs which had an electric power requirement based on the nameplate data of $72.13 \mathrm{~kW}$. The type of lighting consisted of $120 \mathrm{~cm}$ long LED lamps of $20 \mathrm{~W}(74 \%)$, $60 \mathrm{~cm}$ long LED lamps of $8 \mathrm{~W}(1 \%)$, and $9 \mathrm{~W}$ and 7 W LED lamps (13\% and $11 \%$, respectively), as shown in Fig.3.

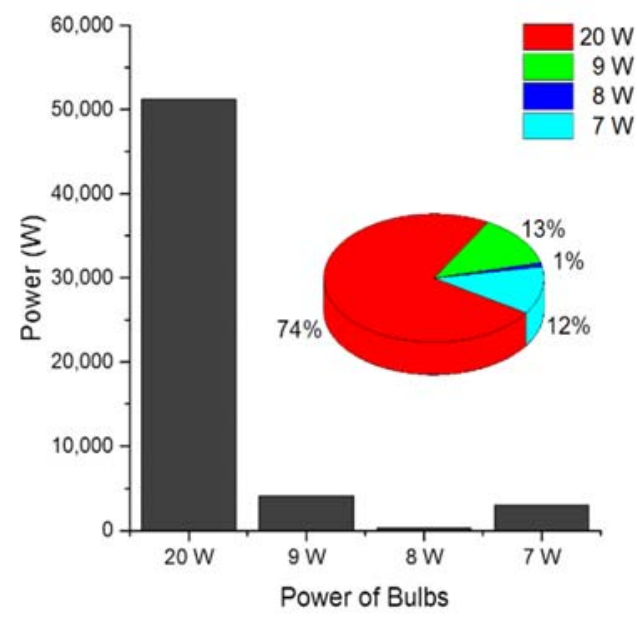

Fig. 3. Number and electric power of lamps according to nameplate data

Overall, on almost every floor in the building there was a high electrical power demand because of the illumination requirements for organizing activities, offices, and teaching with values between about $3.46 \mathrm{~kW}$ and $6.06 \mathrm{~kW}$. The highest power consumption levels were on the $1^{\text {st }}-3^{\text {rd }}$ floors, used for offices and activities and on the $9^{\text {th }}-11^{\text {th }}$ floors, used for laboratories. The $4^{\text {th }}-8^{\text {th }}$ floors were for classrooms and computational laboratories. The ground floor and the fire escape staircase had low power requirements of approximately $2.03 \mathrm{~kW}$ and $2.00 \mathrm{~kW}$, respectively. The area around the building had the lowest power requirement of $0.78 \mathrm{~kW}$, as shown in Fig.4.

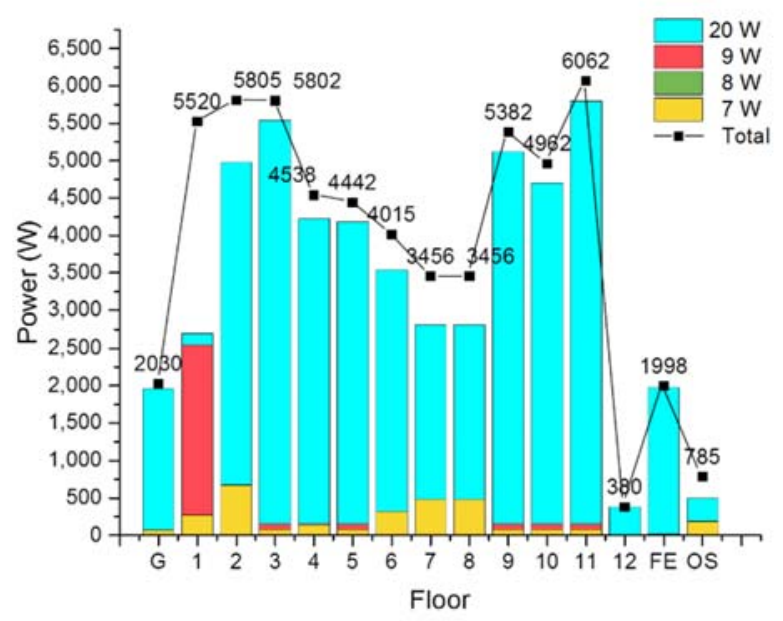

Fig. 4. Different electric power requirements by building location based on calculations using nameplate data

\subsection{Electric power from actual power measurement compared to nameplate data}

The estimation of the building's electrical energy consumption based on actual electrical energy measurements was compared with the estimation according to the nameplate data for each type of light bulb. The mean absolute error (MAE), the root mean square error (RMSE), and the mean absolute percentage error (MAPE) were used to analyze the differences in this study.

Fig. 5 shows a comparison between the meter measurement and evaluation based on nameplate data. The measurement produced a higher wattage than the value from the nameplate for all sizes of lamps. The $20 \mathrm{~W}$ LED bulbs were higher by $4.98 \mathrm{~W}$ having a MAPE value of $24.87 \%$. The $9 \mathrm{~W}$ LED bulbs were higher by $0.86 \mathrm{~W}$ having a MAPE value of 9.54\%. The $8 \mathrm{~W}$ LED lamps were higher by $1.34 \mathrm{~W}$ having a MAPE value of $16.72 \%$, and the $7 \mathrm{~W}$ LED lamps were higher by $0.76 \mathrm{~W}$ having a MAPE value of $10.82 \%$ (Table 1). These differences may have been in part due to losses during the distribution of 
electric current through the conductor wire size, resulting in lost power or increased resistance.

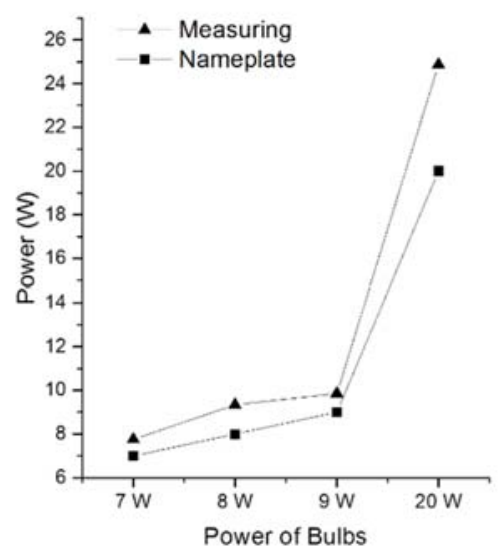

Fig. 5. Electric power difference between measurement and the nameplate

Table 1. Power differences between measurement and label data

\begin{tabular}{|c|c|c|c|}
\hline Lamp power (W) & MAE & RMSE & MAPE (\%) \\
\hline 20 & 4.98 & 5.02 & 24.87 \\
\hline 9 & 0.86 & 0.89 & 9.54 \\
\hline 8 & 1.34 & 1.37 & 16.72 \\
\hline 7 & 0.76 & 0.78 & 10.82 \\
\hline
\end{tabular}

\subsection{Energy consumption and $\mathrm{CO}_{2}$ emissions}

Electrical energy and $\mathrm{CO}_{2}$ emissions can be calculated by multiplying the electrical energy by the emission factor [34]. For Thailand, according to the Electricity Generating Authority's data, the emission factor is $0.5672 \mathrm{kgCO}_{2} / \mathrm{kWh}$ [35]. The current study analyzed power usage during the university's operating hours for periods of 9 hours per day and 24 hours a day for 243 days per year (working days according to Thai government). The results are shown in Table 2.

Table 2. Energy consumption (EC; $\mathrm{MWh}$ ) and $\mathrm{CO}_{2}$ emissions $\left(\mathrm{kgCO}_{2} \times 10^{3}\right)$

\begin{tabular}{|c|c|c|c|c|}
\hline \multirow{2}{*}{$\begin{array}{c}\text { Day } \\
\mathrm{S}\end{array}$} & \multicolumn{2}{|c|}{9 hours/day } & \multicolumn{2}{c|}{24 hours/day } \\
\cline { 2 - 5 } & $\mathrm{EC}$ & $\begin{array}{c}\mathrm{CO}_{2} \\
\text { Emission }\end{array}$ & $\mathrm{EC}$ & $\begin{array}{c}\mathrm{CO}_{2} \\
\text { Emission }\end{array}$ \\
\hline 1 & 0.65 & 0.37 & 1.73 & 0.98 \\
\hline 243 & $\begin{array}{c}157.7 \\
5\end{array}$ & 89.48 & $\begin{array}{c}420.6 \\
7\end{array}$ & 238.61 \\
\hline
\end{tabular}

The energy consumption in the building's lighting system compared with the total energy consumption of the Kasetsart University Sriracha campus in 2018 accounted for $1.64 \%$ for 9 hours use and $4.37 \%$ for 24 hours use.

\subsection{SEC assessment}

The specific energy of the building's lighting system $\left(\mathrm{SEC}_{\mathrm{L}}\right)$ is the amount of energy in the total lighting system in the building, without considering the fire escape area and building surrounds in this study. The results showed that the total energy consumption for 9 hours was 150,235.70 kWh/year and for 24 hours was 400,628.54 kWh/year. The SEC $C_{L}$ can be separated by floor, as shown in Fig.6.

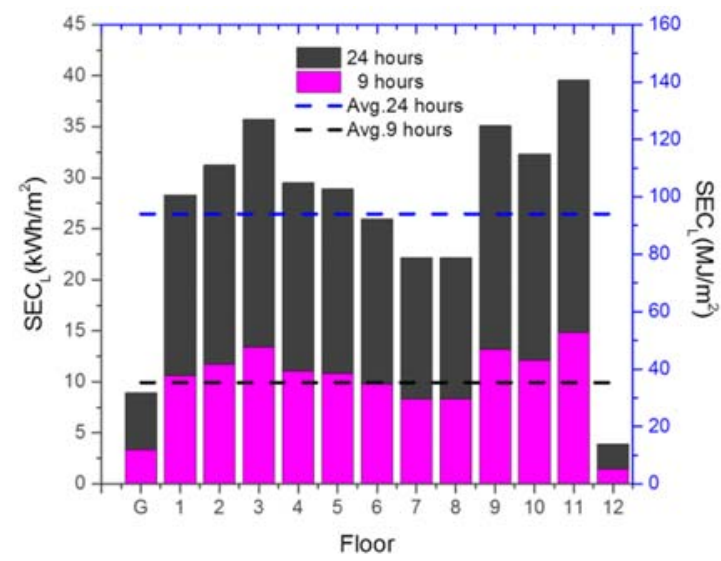

Fig. 6. $S E C_{L}$ by building floor

The SEC $C_{L}$ were considered separately by floor and for operating times of 9 and 24 hours so this baseline could be used to guide energy management in comparisons with the original building values. This allows for the responsible person in each floor layout to formulate policies and compare the savings from the index for each layout. Building operation for 9 hours had average energy consumption of $10.33 \mathrm{kWh} / \mathrm{m}^{2}$ per year or 37.19 $\mathrm{MJ} / \mathrm{m}^{2}$ per year and for 24 hours of usage had 26.45 $\mathrm{kWh} / \mathrm{m}^{2}$ per year or $95.23 \mathrm{MJ} / \mathrm{m}^{2}$ per year. Compared to the university's SEC value of 16.84 $\mathrm{MJ} / \mathrm{m}^{2}$ per year, the $S E C_{L}$ for indoor lighting only was quite high. In addition, compared with the SEC values surveyed among tertiary institutions or universities with an area of less than $50,000 \mathrm{~m}^{2}$, which averaged $36.42 \mathrm{kWh} / \mathrm{m}^{2}$ per year [17], the building in the current study used less energy. While the average annual energy consumption per capita is $114.31 \mathrm{kWh}$ for 9 hours and $304.84 \mathrm{kWh}$ for 24 hours, which are low if compared with the study of certain buildings for example the study of public buildings in Novi Sad [36,37]. However, combining the light systems with other systems such as air conditioning which is the highest energy use system and including equipment and electrical appliances to support teaching and learning, the building's SEC value would be higher than the 
standard. It should be noted that the results of this analysis are only predictions. In official use of the building, all floors are based on actual usage and the energy consumption data are collected from actual electricity meters. The SEC value reflects actual usage.

Therefore, from the data shown, it is essential to prepare energy-saving measures for the lighting system to achieve timely and quick energy-saving without affecting teaching or other activities in the building. In addition, energy conservation in the lighting system is not complicated and is easy to implement. Furthermore, everyone inside and outside the organization can do apply this with a low investment. An elementary energy conservation plan in an appropriate system for the building based on the current evaluation and related research can be summarized as follows:

- Raise awareness and campaigning to turn off lights in non-activity areas [38,39];

- Reduce the number of lamps in areas where the light exceeds the set standard [40] or in areas where natural light can be used [41], which will also reduce the heat build-up due to incandescent lamps [42];

- Modify the light control switch in each area or add a control switch to select the appropriate area of the room [43];

- Change the size of the lamp to have lower the power, for example, a 20 W LED lamp, which is the largest may be replaced with tube lighting, such as T5 tubes;

- Use pull switches in the office [44] or motion sensors [45] to have power in real-time, or sensors that detect the natural environment to control energy use [46];

- Use an automatic on-off system during non-use periods, such as setting on-off times to be consistent with working hours and lunch breaks [47];

- Replace cloudy or transparent lamp covers for the best use of the light;

- Plan classroom size according to the number of learners to avoid small numbers in a large classroom.

\section{CONCLUSION}

The results of the examination of the new Science Building, including estimation of the power consumption of the lighting system can be summarized as:
- The building has a total electric power requirement equivalent to $72.13 \mathrm{~kW}$ of which $74 \%$ is for $20 \mathrm{~W}$ light bulbs, followed by $9 \mathrm{~W}$ and 7 W light bulbs, respectively;

- Most of the electricity consumption is in office area and laboratories;

- The $20 \mathrm{~W}$ lamps different the most from the nameplate data usage, being $4.97 \mathrm{~W}$ higher;

- The electrical energy consumption and $\mathrm{CO}_{2}$ emissions for a usage period of 9 hours per day were 157,753.73 kWh/year and 89,477.92 $\mathrm{kgCO}_{2}$ /year and for $1.64 \%$ and $4.37 \%$, respectively, for 24 hours of total university power consumption;

- The $S E C_{L}$ values for the indoor lighting alone were high compared to average university SEC values. Including the air conditioning system would result in a significantly higher SEC value;

- There are several ways to implement energysaving measures in the lighting system. Initially there is a low investment cost and widespread user implementation by creating awareness of energy saving. Additional options include reducing the number of bulbs in unused areas and teaching management to allocate class rooms whose size is suitable for the number of students. Furthermore, using natural light will help to reduce lighting energy consumption.

Surveying and collecting system data in the preoperation period of a building facilitates measurement and does not interrupt teaching or other activities. In addition, information on systems or electrical devices should be continuously updated to enable efficient and accurate energy assessment and energy-saving management.

\section{ACKNOWLEDGEMENT}

This work was financially supported by the Faculty of Science at Si Racha, Kasetsart University Si Racha campus.

\section{REFERENCES}

[1] O. Rewthong, B. Eamthanakul, S. Chuarung, S. Sansiribhan, N. Luewarasirikul, Status of total electric energy consumption in university. Procedia-Social and Behavioral Sciences, 197, 2015: 1166-1173. https://doi.org/10.1016/j.sbspro.2015.07.373

[2] S. Wattana, B. Wattana, An Assessment of the Impacts of Renewable Energy Policies on the 
Thai Electricity Generation Sector. International Energy Journal, 20(2), 2020: 101114

[3] K. Amasyali, N. El-Gohary, Building lighting energy consumption prediction for supporting energy data analytics. Procedia Engineering, 145, 2016: 511-517.

https://doi.org/10.1016/j.proeng.2016.04.036

[4] N.H. Moadab, T. Olsson, G. Fischl, M. Aries, Smart versus conventional lighting in apartments-Electric lighting energy consumption simulation for three different households. Energy and Buildings, 244, 2021: 111009.

https://doi.org/10.1016/i.enbuild.2021.111009

[5] M.U. Khalid, M. Gul, M.M. Aman, A. Hashmi, Energy conservation through lighting audit. 2012 IEEE International Conference on Power and Energy (PECon), $2^{\text {th }}-5^{\text {th }}$ December, 2012, Kota Kinabalu, Malaysia, pp.840-845.

https://doi.org/10.1109/PECon.2012.6450335

[6] P. Pimdee, N. Thiengkamol, T. Thiengkamol, Causal Relationship Model of Electrical Energy Conservation. European Journal of Social Sciences, 32(3), 2012: 306-315.

[7] N.N.A. Bakar, M.Y. Hassan, H. Abdullah, H.A. Rahman, M.P. Abdullah, F. Hussin, M. Bandi, Energy efficiency index as an indicator for measuring building energy performance: $A$ review. Renewable and Sustainable Energy Reviews, 44, 2015: 1-11.

https://doi.org/10.1016/i.rser.2014.12.018

[8] A. Thewes, S. Maas, F. Scholzen, D. Waldmann, A. Zürbes, Field study on the energy consumption of school buildings in Luxembourg. Energy and Buildings, 68, 2014: 460-470.

https://doi.org/10.1016/i.enbuild.2013.10.002

[9] Z. Nagy, F.Y. Yong, A. Schlueter, Occupant centered lighting control: A user study on balancing comfort, acceptance, and energy consumption. Energy and Buildings, 126, 2016: 310-322, https://doi.org/10.1016/j.enbuild.2016.05.075

[10] L.T. Doulos, A. Kontadakis, E.N. Madias, M. Sinou, A. Tsangrassoulis, Minimizing energy consumption for artificial lighting in a typical classroom of a Hellenic public school aiming for near Zero Energy Building using LED DC luminaires and daylight harvesting systems. Energy and Buildings, 194, 2019: 201-217. https://doi.org/10.1016/j.enbuild.2019.04.033

[11] L. Xu, Y. Pan, Y. Yao, D. Cai, Z. Huang, N. Linder, Lighting energy efficiency in offices under different control strategies. Energy and Buildings, 138, 2017: 127-139.

https://doi.org/10.1016/i.enbuild.2016.12.006

[12] M.C. Dubois, Å. Blomsterberg, Energy saving potential and strategies for electric lighting in future North European, low energy office buildings: A literature review. Energy and buildings, 43(10), 2011: 2572-2582.

https://doi.org/10.1016/i.enbuild.2011.07.001

[13] G. Yun, K.S. Kim, An empirical validation of lighting energy consumption using the integrated simulation method. Energy and Buildings, 57, 2013: 144-154.

https://doi.org/10.1016/j.enbuild.2012.10.028

[14] Coordinating center for energy conservation building design, Department of Alternative Energy Development and Efficiency, Ministry of Energy, Building Design Guidelines for Energy Conservation, 2019. http://new.2ebuilding.com/sites/default/files/2021-

05/guildline-bec-60.pdf (Accessed 15.11.2020)

[15] G. Yingming, X. Mingdong, Z. Huanyue, G. Xu, L. Ping, Z. Nianyu, Study on distributed individuation lighting model and analysis to energy consumption character. Energy and Buildings, 151, 2017: 45-52.

https://doi.org/10.1016/j.enbuild.2017.06.036

[16] L. Bellia, G. Spada, A. Pedace, F. Fragliasso, Methods to evaluate lighting quality in educational environments. Energy Procedia, 78, 2015: 3138-3143.

https://doi.org/10.1016/i.egypro.2015.11.770

[17] Department of Alternative Energy Development and Efficiency, Ministry of Energy, Knowledge set manual Energy Conservation for Educational Institutions, first ed. n.p., 2007.

[18] S. Chirarattananon, P. Chaiwiwatworakul, V.D. Hien, P. Rakkwamsuk, K. Kubaha, Assessment of energy savings from the revised building energy code of Thailand. Energy, 35(4), 2010: 1741-1753.

https://doi.org/10.1016/j.energy.2009.12.027

[19] V. Nakthong, K. Kubaha, Development of a Sustainability Index for an Energy Management System in Thailand. Sustainability, 11(17), 2019: 4587. https://doi.org/10.3390/su11174587

[20] B.N. Getu, H.A. Attia, Electricity audit and reduction of consumption: campus case study. International Journal of Applied Engineering Research, 11(6), 2016: 4423-4427.

[21] G.Y. Yun, H.J. Kong, H. Kim, J.T. Kim, A field survey of visual comfort and lighting energy 
consumption in open plan offices. Energy and Buildings, 46, 2012: 146-151. https://doi.org/10.1016/i.enbuild.2011.10.035

[22] K.R. Shailesh, S. Tanuja, M. Kumar, R.A. Krishna, Energy consumption optimisation in classrooms using lighting energy audit, National Conference on Challenges in Research \& Technology in the Coming Decades (CRT 2013), 27-28 ${ }^{\text {th }}$ September 2013, Ujire, India, pp.1-5.

[23] G. Salvadori, F. Fantozzi, M. Rocca, F. Leccese, The energy audit activity focused on the lighting systems in historical buildings. Energies, 9(12), 2016: 998.

https://doi.org/10.3390/en9120998

[24] F. Leccese, F. Fantozzi, V. Vandelanotte, G. Salvadori, M. Rocca, T. Corucci, Energy consumptions, operating costs and $\mathrm{CO}_{2}$ emission of LED lighting in office buildings, In $15^{\text {th }}$ CIRIAF National Congress Environmental Footprint and Sustainable Development, $9^{\text {th }}$. $11^{\text {th }}$ April 2015, Perugia, Italy, pp.1-16.

[25] T. Kim, B. Kang, H. Kim, C. Park, W.H. Hong, The study on the Energy Consumption of middle school facilities in Daegu, Korea. Energy Reports, 5, 2019: 993-1000. https://doi.org/10.1016/j.egyr.2019.07.015

[26] S.B.M. Ali, M. Hasanuzzaman, N.A. Rahim, M.A.A. Mamun, U.H. Obaidellah, Analysis of energy consumption and potential energy savings of an institutional building in Malaysia. Alexandria Engineering Journal, 60(1), 2021: 805-820.

https://doi.org/10.1016/j.aej.2020.10.010

[27] A. Alajmi, Energy audit of an educational building in a hot summer climate. Energy and Buildings, 47, 2012: 122-130. https://doi.org/10.1016/i.enbuild.2011.11.033

[28] O.K. Larsen, R.L. Jensen, T. Antonsen, I. Strømberg, Estimation methodology for the electricity consumption with daylight-and occupancy-controlled artificial lighting. Energy Procedia, 122, 2017: 733-738. https://doi.org/10.1016/j.egypro.2017.07.388

[29] W. Wongsapai, Analysis of Energyreporting and Verification System Under Thailand Energy Management System. Energy Procedia, 110, 2017: 38-44.

https://doi.org/10.1016/j.egypro.2017.03.103

[30] A. Fichera, G. Inturri, P. La Greca, V. Palermo, A model for mapping the energy consumption of buildings, transport and outdoor lighting of neighbourhoods. Cities, 55, 2016: 49-60. https://doi.org/10.1016/i.cities.2016.03.011
[31] S. El Sayary, O. Omar, Designing a BIM energy-consumption template to calculate and achieve a net-zero-energy house. Solar Energy, 216, 2021: 315-320.

https://doi.org/10.1016/j.solener.2021.01.003

[32] A.B.R. González, J.J.V. Díaz, A.J. Caamano, M.R. Wilby, Towards a universal energy efficiency index for buildings. Energy and Buildings, 43(4), 2011: 980-987.

https://doi.org/10.1016/i.enbuild.2010.12.023

[33] Taro Yamane, Statistics: An Introductory Analysis, Third Ed. Harper and Row, New York, 1973.

[34] Y. Wang, T. Sun, Life cycle assessment of $\mathrm{CO}_{2}$ emissions from wind power plants: Methodology and case studies. Renewable Energy, 43, 2012: 30-36.

https://doi.org/10.1016/j.renene.2011.12.017

[35] Electricity Generating Authority of Thailand, Greenhouse Gas Management: Carbon Dioxide Emissions, 2017. https://www.egat.co.th/index.php?option=co $\mathrm{m}$ content\&view $=$ article\&id $=2634$ \& temid $=12$ 7\&catid=37, (Accessed 6 December 2020)

[36] Ašonja, A., Rajković, J. (2017). Energy Consumption Analysis of the Mapped Public Building in the City of Novi Sad, VII International Conference Industrial Engineering and Environmental Protection 2017 (IIZS 2017), October 12-13 ${ }^{\text {th }}, 2017$, Zrenjanin, Serbia, pp.218-224.

[37]A. Ašonja, Energy Balances of Public Buildings in the City of Novi Sad. ANNALS of Faculty Engineering Hunedoara - International Journal of Engineering, 15(2), 2017: 81-84.

[38] Q. Song, J. Li, H. Duan, D. Yu, Z. Wang, Towards to sustainable energy-efficient city: a case study of Macau. Renewable and Sustainable Energy Reviews, 75, 2017: 504-514. https://doi.org/10.1016/i.rser.2016.11.018

[39] M. Jäger, S. Luitjens, V. Mihajlović, F. Snijder, T. Tsoneva, H. Weda, A. Weffers-Albu, Raising awareness on energy consumption of household devices, Sixth International Symposium on Environmentally Conscious Design and Inverse Manufacturing, $7^{\text {th }}-9^{\text {th }}$ December 2009, Sapporo, Japan, pp.145-550.

[40] R. Müllner, A. Riener, An energy efficient pedestrian aware Smart Street Lighting system. International Journal of Pervasive Computing and Communications, 7(2), 2011: 147-161. https://doi.org/10.1108/17427371111146437

[41] D.H. Li, S. Li, W. Chen, Estimating the switching frequency and energy saving for daylight- 
linked lighting on-off controls. Energy Procedia, 158, 2019: 2878-2883.

https://doi.org/10.1016/i.egypro.2019.01.939

[42] K.C. Lawrence, B. Park, G.H.W. Windham, C.N. Thai, Evaluation of LED and tungsten-halogen lighting for fecal contaminant detection. Applied engineering in agriculture, 23(6), 2007: 811-818.

https://doi: $10.13031 / 2013.24048$

[43] I. Din, J. Kim, H. Kim, Joint power and beam angle control for energy efficiency in lighting control systems. Journal of applied research and technology, 11(3), 2013: 402-407.

[44] B. Roisin, M. Bodart, A. Deneyer, P. D’Herdt, Lighting energy savings in offices using different control systems and their real consumption. Energy and Buildings, 40(4), 2008: 514-523. https://doi.org/10.1016/j.enbuild.2007.04.006

[45] J.W. Lee, Y.I. Kim, Energy Saving of a University Building Using a Motion Detection Sensor and Room Management System. Sustainability, 12(22), 2020: 9471. https://doi.org/10.3390/su12229471

[46] C. Yin, S. Zhou, S. Wu, W. Wang, X. Wei, Y. Cheng, $X$. Huang, Tracking the minimum energy consumption for the lighting system though modified extremum seeking method. Energy Procedia, 105, 2017: 2583-2588. https://doi.org/10.1016/j.egypro.2017.03.741

[47] A. Guillemin, N. Morel, An innovative lighting controller integrated in a self-adaptive building control system. Energy and Buildings, 33(5), 2001: 477-487.

https://doi.org/10.1016/S03787788(00)00100-6 